\title{
Article \\ Calorific Characteristics of Larch (Larix decidua) and Oak (Quercus robur) Pellets Realized from Native and Torrefied Sawdust ${ }^{\dagger}$
}

\author{
Aurel Lunguleasa * ${ }^{\mathbb{D}}$, Cosmin Spirchez and Alin M. Olarescu
}

Citation: Lunguleasa, A.; Spirchez, C.; Olarescu, A.M. Calorific Characteristics of Larch (Larix decidua) and Oak (Quercus robur) Pellets Realized from Native and Torrefied Sawdust. Forests 2022, 13, 361. https://doi.org/10.3390/f13020361

Academic Editor: Antonios

Papadopoulos

Received: 1 February 2022

Accepted: 19 February 2022

Published: 21 February 2022

Publisher's Note: MDPI stays neutral with regard to jurisdictional claims in published maps and institutional affiliations.

Copyright: (C) 2022 by the authors. Licensee MDPI, Basel, Switzerland. This article is an open access article distributed under the terms and conditions of the Creative Commons Attribution (CC BY) license (https:// creativecommons.org/licenses/by/ $4.0 /)$.
Wood Processing and Design of Wooden Product Department, Transilvania University of Brasov, 29 Street Eroilor 500038 Brasov, Romania; cosmin.spirchez@unitbv.ro (C.S.); a.olarescu@unitbv.ro (A.M.O.)

* Correspondence: lunga@unitbv.ro

† This paper is partially based on the conference paper: Lunguleasa, A.; Spirchez, C. Energetic aspects of oak and larch pellets obtained from sawdust waste improved by torrefaction. In Proceedings of the 8th International Conference on Sustainable Solid Waste Management, Thessaloniki, Greece, 23-26 June 2021; pp. 1-8. http:/ / uest.ntua.gr/thessaloniki2021/pdfs/THESSALONIKI_2021_Lunguleasa_Sprirchez.pdf.

\begin{abstract}
This research aimed to evaluate the calorific characteristics of two biomasses from larch and oak sawdust in the form of native or torrefied pellets. Some calorific features of these two kinds of biomasses, such as ash content, higher and lower calorific values, calorific density and many others were highlighted, allowing for a comparison between oak and larch torrefied/not torrefied pellets. Installations and methods used for the process of torrefaction and for highlighting some of the calorific features were also evaluated. As a result of experiments, it was demonstrated that the larch and oak pellets were different in terms of density, but that after thermal treatment, the calorific values of both increased considerably. The investigations evidenced some increases in calorific value, up to $15.8 \%$, for both the larch and oak sawdust/pellets. One of the main conclusions of this research was that, even though the role of biomass has diminished considerably in the last few decades, its role as a sustainable fuel remains relevant. Its use will become more widespread when the world's population understands that fossil fuels are depletable and that they must be replaced by renewable fuels such as biomass.
\end{abstract}

Keywords: biomass; calorific density; calorific value; larch; oak; torrefied pellet

\section{Introduction}

Generally speaking, the calorific value of fuels differs significantly from one fuel type to another. These differences are usually measurable between gaseous and solid fuels. However, solid and liquid fuels have the same rules when it comes to measuring calorific value and there are no quantifiable differences between them [1-3]. Heat in the form of hot air, obtained by heating the cold air in a given room or heating a plateaux of some kind, can be used in the food preparation or manufacturing industries for warming up the press plateau, etc. $\mathrm{CO}_{2}$ from the air is captured inside the wooden biomass of trees during the growth process (about 90-100 years), forming a closed circuit due to the amount of $\mathrm{CO}_{2}$ that was absorbed by the trees during the growth process being equal with that which is obtained during complete combustion (some minutes or hours). In other words, it would be accurate to say that the same amount of $\mathrm{CO}_{2}$ is obtained when wooden waste/biomass is decomposed in an open space over a few years. Therefore, the use of woody waste/biomass as energy for human needs is recommended [4,5]. Natural gases have obtained a privileged position as fuels because they burn more cleanly than oil or coal, namely because that the process produces a low amount of pollution in the air. More accurately, for the same amount of fuel that is burned, natural gases spread into the atmosphere half the toxicity of coal. Also, the burning of natural gases does not release as much sulphur dioxide or 
nitrates [6-8] than coals. However, one of the main problems in the field of fuels is that the natural gases are not renewable and their reserves will be depleted in the next years [9]. That is why, nowadays, thenatural gases merely represent a temporary solution in the transition to more regenerative fuels.

The term biomass pertains to large renewable energy resources such as solar, wind, geo-thermal and water energy [9]. The use of this kind of fuel has been increasing every year and is expected to become the most used type of fuel in the next few years (Figure 1).

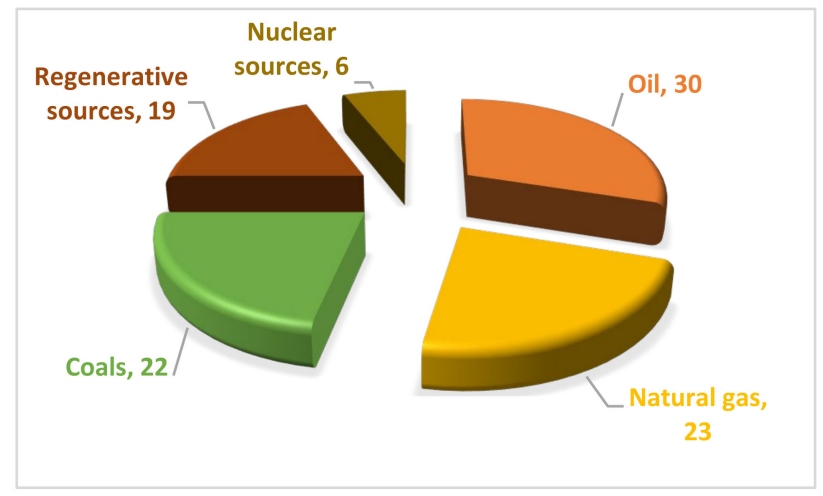

Figure 1. The world's energy resources [9].

Kambo and Dutta [1] highlighted some methods to improve raw sources of energy via thermal treatments. Natural waste taken from Miscanthus spp., pretreated by torrefaction and compacted in the form of pellets, was researched in relation to its mechanical and energy characteristics, for the purpose of improving some features. The effective density and calorific density of torrefied pellets increased from $834 \mathrm{~kg} / \mathrm{m}^{3}$ and $15.7 \mathrm{GJ} / \mathrm{m}^{3}$ to $1036 \mathrm{~kg} / \mathrm{m}^{3}$ and $26.9 \mathrm{GJ} / \mathrm{m}^{3}$, respectively. Akinrinola [7] showed that the thermal treatment of torrefied biomass from Nigeria (resulting from two wooden species and two other waste crops) was able to improve some fuel features, regardless of whether they were used for industrial or domestic energy sources. Other authors [10] took only waste of only two wood species, Liriodendron tulipifera L. and Larix kaemferi C., in order to make pellets for the purpose of improving resistance and calorific value by using lignin powder as an additive. Peng et al. [11] stated that good pellets can be realized from particles with small dimensions. A complete analysis of native and torrefied pellets was made by Kumar et al. [6], who identified the benefits of using wooden waste in combination with crushed coal.

Some parameters of the torrefaction/pelletizing process were made by Rudolfsson et al. [12]. This study was focused on the moisture content, particle dimensions and the extrusion channel length. Oh et al. [13] researched the pelletizing/torrefying process of sawdust waste from larch (Larix Kaempferi C.) and poplar (Liriodendron Tulipifera L.) species. Nhuchhen and Basu [14] analyzed a new methodology for replacing nitrogen, which is very expensive, with pressurized air. Meanwhile, Kudo et al. [15] replaced inert nitrogen gas, which results in the poor adhesion of coal shale in pellets, with wet saturated steam. The resistance of the pellets obtained because of this change increased by five times. Peng et al. [16] observed that the biomass should first be torrefied and then compacted by pelletizing. Thus, pellets with superior features, namely a high resistance to water, can be obtained.

Eseyin et al. [17] stated that torrefied biomass in the form of pellets/briquettes or native biomass has a high calorific energy, is resistant to water and fungus and has a longer storage time. Additionally, the advantages of using biomass include the fact that biomass is an environmentally friendly fuel that produces substantially lower $\mathrm{CO}_{2}$ emissions compared to fossil fuel. Granados et al. [18] studied the influence of the torrefaction installation on the process, performed in two stages, for small wood particles of $0.5-1 \mathrm{~mm}$ from poplar species. During the torrefaction process, instead of an inert nitrogen atmosphere, the resulting gases were used for the heat treatment process. The mass loss was $34 \%$ 
and the calorific value increased by $40 \%$ when the torrefaction temperature was $300{ }^{\circ} \mathrm{C}$. Okoro et al. [19] studied the role of wooden biomass obtained from two species of pine versus fossil resources, especially when they were thermally treated to obtain syngas via pyro-gasification. The optimum thermal treatment was at $300{ }^{\circ} \mathrm{C}$ for $45 \mathrm{~min}$. The calorific value increased by $57 \%$. Olugbade and Ojo [20] determined a number of the energy characteristics of biomass and in particular for heat-treated agricultural biomass by torrefaction in an inert nitrogen atmosphere. Torrefaction is considered to be a process of medium pyrolysis. Alokika and Singh [21] optimized the parameters of the torrefaction process for an acacia species. TGA, SEM and FTIR analyzes showed an $18 \%$ higher calorific value, a $75 \%$ increase in fixed carbon, and an energy efficiency at $252{ }^{\circ} \mathrm{C}$ and a treatment time of $60 \mathrm{~min}$, compared to raw materials. Pérez et al. [22] treated four fast-growing species from Colombia, namely Gmelina, two species of pine and one type of eucalyptus, respectively. No major differences were found between the energetic properties of these species (a volatile content of $70 \%$, calorific value $18.7 \mathrm{MJ} / \mathrm{kg}$ and ash content below $1 \%$ ) but they behaved differently during the thermal treatment process. It has also been shown via chemical analysis that only hemicellulose was degraded during torrefying, whereas lignin and cellulose remaining undegraded. Lee et al. [23] used sewage sludge for torrefaction to enrich energetic properties. The obtained product was very similar to coal. The spontaneous ignition of this fuel has been shown to occur at a temperature of $211^{\circ} \mathrm{C}$. Further research has focused on both the use of other residues obtained from other industries, such as from the coffee [24] and paper [25] industries, or the internationally correlation of standardized properties [26].

An initial deduction that can be made from the above studies in the field of sawdust thermal torrefaction is that, although torrefaction is a very efficient treatment, the nitrogen flow used during biomass torrefying is not cheap and requires complex installation. This is the reason why some simpler torrefaction methods have been tested to achieve the same effects $[14,15,18]$. A second conclusion that can be made is that more and more studies refer to the use of lignocellulosic biomass as a safe and sustainable method of transitioning from fossil fuel energy to the energy obtained from renewable sources.

Objectives: The aim of this paper was to improve the calorific features of the sawdust of two species (one of the softwoods and another of the hardwoods, in order to observe their different behaviors), torrefied over $200{ }^{\circ} \mathrm{C}$ without the admission of air during the thermal process. Some calorific characteristics were tasted for the native/torrefied pellets. In particular, the influence of moisture content on the calorific value of the two analyzed species was studied.

\section{Materials and Methods}

For the experimental, two lignocellulosic biomasses in the form of native sawdust were used. Sawdust was obtained from larch and oak timber. Waste sawdust was collected from a circular saw machine at a university wood processing workshop (Transilvania University of Brasov, Brasov, Romania) when the two wood species, in the form of timber, were processed. As the sawdust purchased had large particles and spalls, it was sorted using a $6 \mathrm{~mm} \times 6 \mathrm{~mm}$ mesh sieve. After sorting, only the fraction that fell through the sieve was taken, with the remainder that remained above the sieve (about $12 \%$ ) being eliminated. Next, the moisture of the sawdust was determined, obtaining values within the limits of $10 \pm 0.6 \%$ (because the dry timber was used due to the needs of the workshop). The experimental process involved three steps: a first step, in which the characteristics of the raw material were determined; a second step, in which the small sawdust was torrefied and the native/torrefied pellets were made; and a third step for testing the obtained pellets.

Granulometry. In order to determine the characteristics of the sawdust, its granulometry was determined using sieves with $4 \mathrm{~mm} \times 4 \mathrm{~mm}, 3.15 \mathrm{~mm} \times 3.15 \mathrm{~mm}, 2 \mathrm{~mm} \times 2 \mathrm{~mm}$, $1.25 \mathrm{~mm} \times 1.25 \mathrm{~mm}$ and $0.8 \mathrm{~mm} \times 0.8 \mathrm{~mm}$ meshes arranged on an electric device with vibration. Six sawdust samples were used for each species analyzed, and the results obtained in the form of masses were transformed into percentage values by reporting the value of 
the mass remaining on the sieve to the total mass of the sample. As an example, Equation (1) shows how the percentage of chips was determined for the fraction $3.15 \mathrm{~mm} \times 3.15 \mathrm{~mm}$.

$$
\mathrm{P}_{3.5}=\left(\mathrm{m}_{3.15}: \mathrm{m}_{\mathrm{s}}\right) \times 100[\%]
$$

where: $\mathrm{P}_{3.15}$-the participation percentage of the fraction of $3.15 \mathrm{~mm} \times 3.15 \mathrm{~mm}$ from the total chips in $\% ; \mathrm{m}_{3.15}$ is the mass of the fraction of $3.15 \mathrm{~mm} \times 3.15 \mathrm{~mm}$ which remains above the respective sieve in $\mathrm{g}$; and $\mathrm{m}_{\mathrm{s}}$ is mass of the whole sample in $\mathrm{g}$.

Similar to Equation (1), the other five percentage values were determined for sieves with meshes of $4 \mathrm{~mm} \times 4 \mathrm{~mm}, 2.5 \mathrm{~mm} \times 2.5 \mathrm{~mm}, 1.25 \mathrm{~mm} \times 1.25 \mathrm{~mm}, 0.8 \mathrm{~mm} \times 0.8$ $\mathrm{mm}, 0.4 \mathrm{~mm} \times 0.4 \mathrm{~mm}$ and the rest (which remained below the sieve of $0.4 \mathrm{~mm} \times 0.4 \mathrm{~mm}$ and was collected in the existing collector cylinder). The values for all six groups of tests were then averaged, and, based on these, the graphs of variation of the obtained values were realized.

Bulk sawdust features [26]. In the case of sawdust, its bulk density was determined by using a graduated cylinder to determine the volume of sawdust, the calculation relation being as follows Equation (2):

$$
\varrho=\left(\mathrm{m}_{\mathrm{t}}-\mathrm{m}_{\mathrm{c}}\right):\left(\pi \times \mathrm{d}^{2} \times \mathrm{h}\right) \times 10^{6}\left[\mathrm{~kg} / \mathrm{m}^{3}\right]
$$

where: $m_{t}$ is the total mass of the sawdust with the cylinder in $g ; m_{c}$ is mass of the empty cylinder in $\mathrm{g}$; $\mathrm{d}$ is inner diameter of the cylinder in $\mathrm{mm}$; and $\mathrm{h}$ is height of the sawdust layer inside the cylinder in $\mathrm{mm}$.

This bulk sawdust density was used to determine the expanding or compression coefficient of the sawdust used, using the following two equations, Equation (3):

$$
\mathrm{Ke}=\varrho \mathrm{w}: \varrho \mathrm{s} ; \mathrm{Kc}=\varrho \mathrm{ws}: \varrho \mathrm{s}
$$

where: Ke is the expanding coefficient; $K_{c}$ is the compression coefficient; $\varrho_{\mathrm{w}}$ is density of wood in $\mathrm{kg} / \mathrm{m}^{3}$; and $\varrho_{\mathrm{s}}$ is the bulk density of sawdust in $\mathrm{kg} / \mathrm{m}^{3}$.

The density of the solid wood was determined by taking 10 specimens with dimensions of $20 \mathrm{~mm} \times 20 \mathrm{~mm} \times 30 \mathrm{~mm}$ from the remains of the timber pieces, with the mass in lreation to their volume being reported. This Ke coefficient was used to determine the compressibility of the sawdust, comparing the density of the solid wood from which it came, with this of the sawdust with respect to its dimensional peculiarities.

Obtaining pellets from native sawdust. Pellets with a diameter of $10 \mathrm{~mm}$ were obtained from the sorted sawdust, using a laboratory pelletizing device (as part of calorimeter apparatus). The main characteristics that were determined for these native pellets were size, moisture content, unit density, bulk density, higher and lower calorific value (HCV, LCV), calorific efficiency, combustion time and calorific density, etc.

Ash content determination. A well-known and standardized method was used to determine the ash content of the sawdust (ASTM E1755-01) [25]. The wood sawdust was dried in a laboratory oven at $105{ }^{\circ} \mathrm{C}$ for $2 \mathrm{~h}$ in order to eliminate the influence of moisture content on the ash content. For this purpose, metal crucibles made of nickel-chromium alloys that are resistant to high temperatures were used. These were cleaned thoroughly and then burned on a butane gas flame, before being cooled in a desiccator and weighed up to three decimal places on a Kern, Germany electronic scale. A small amount of less than $1 \mathrm{~g}$ of sawdust was then placed on the surface of the crucible in 2-3 layers and then the crucibles were weighed again. In order to protect the inner cavity of the calciner (Protherm, Ploiesti, Romania), the sawdust crucible was burned on a flame of butane gas until there was no more flame and smoke, and the ash obtained had a black color. At this point, the crucible with the ashes was weighed again with the help of the high-precision balance up to 3 decimal. Next, the crucibles were introduced into the calcination furnace for a period of about $30 \mathrm{~min}$ at a temperature of $650{ }^{\circ} \mathrm{C}$. After that, in order to determine if the calcination process was finished, the crucibles were checked to see if they had a light greyish ash 
color and that there was no longer any spark and carbon. When the ash content was determined, the sawdust samples were completely dried out in an oven and the crucible mass was also kept into consideration, as seen in Equation (8) [19-21]. The black ash and the calcined ash masses were determined as proportions with the following relationships using Equations (4) and (5):

$$
\begin{aligned}
& \text { BAC }=\left(m_{b a+c}-m_{c}\right):\left(m_{s+c}-m_{c}\right) \times 100[\%] \\
& C A C=\left(m_{c a+c}-m_{c}\right):\left(m_{s+c}-m_{c}\right) \times 100[\%]
\end{aligned}
$$

where: $m_{b a+c}$ is mass of the black ash and the crucible in $g ; m_{c a+c}$ is the mass of the calcinated ash and the crucible in $\mathrm{g} ; \mathrm{m}_{\mathrm{s}+\mathrm{c}}$ is the mass of specimen and the crucible in $\mathrm{g}$; and $\mathrm{m}_{\mathrm{C}}$ is the empty crucible mass in $\mathrm{g}$.

Torrefaction of sawdust. Lignocellulosic biomass in the form of larch and oak sawdust, taken from a circular saw and sorted, was subjected to a torrefaction process inside of the calcination furnace STC 18.26 (Ploiesti, Romania) without air admission. Different temperatures, of 200,220, 240, 260, 280 and $300{ }^{\circ} \mathrm{C}$, and times, of 3, 5 and $10 \mathrm{~min}$, were used to highlight its calorific properties. Each type of torrefying regime was performed individually (not progressively, from a lower treatment to a higher one), obtaining a total of 18 types of regimes for larch and another 18 for oak sawdust. For each regimen, 10 individual and distinct samples were used. The heat treatment was performed without oxygen intake. The torrefied samples were cooled and subjected to specific tests, mainly to determine mass loss. This material was then transformed into torrefied pellets so that they had the same dimensional characteristics as the native ones (untreated). The torrefaction process was performed on a small amount of wooden sawdust for each temperature and time [22-26]. During this period, some changes in the sawdust color occurred [27-29]. The mass loss percentage (ML) of the torrefied sawdust was determined with using Equation (6):

$$
\mathrm{ML}=\left(\mathrm{m}_{\mathrm{i}}-\mathrm{m}_{\mathrm{f}}\right): \mathrm{m}_{\mathrm{i}} \times 100[\%]
$$

where: $m_{i}$ is the initial sawdust mass, before torrefaction, in $g$ and $m_{f}$ is the final sawdust mass, after torrefaction, in $\mathrm{g}$.

The ML values represented the mean of 10 tests, each of them for all periods, temperature, and wooden species.

Density of pellets. The densities of the native and treated pellets were obtained as the ratio between their mass and volume when they had the same Mc, i.e., $10 \%$. Because the form of the pellets had been approximated as a right cylinder (their heads were polished in order to for them to have a perpendicular to length cross section), the relationship of density was determined by Equation (7):

$$
\varrho=4 \times \mathrm{m}:\left(\pi \times \mathrm{d}^{2} \times \mathrm{l}\right) \times 10^{6}\left[\mathrm{~kg} / \mathrm{m}^{3}\right]
$$

where: $\mathrm{m}$ is the pellet's mass in $\mathrm{g}$; $\mathrm{d}$ is the pellet's diameter in $\mathrm{mm}$; and 1 is the pellet's length in $\mathrm{mm}$.

High and low calorific values. The apparatus that was used to determine the calorific energy of the solid biomass in the form of sawdust pellets was the calorimeter bomb, type XRY-1C, offered by Shanghai Changji Trading Company Limited., China. The calibration of the calorimetric apparatus was performed before testing by using benzoic acid that had a calorific value of $26,463 \mathrm{~kJ} / \mathrm{kg}$. By using this value, the coefficient $\mathrm{k}$ was obtained with the same method of determination and the same CV relationship using Equation (8).

$$
\mathrm{CV}=\left(\mathrm{k} \times\left(\mathrm{T}_{\mathrm{f}}-\mathrm{T}_{\mathrm{i}}\right)-\mathrm{qi}\right): \mathrm{m}[\mathrm{kJ} / \mathrm{kg}]
$$

where: $\mathrm{CV}$ is the best calorific value for $0 \% \mathrm{Mc}$ in $\mathrm{KJ} / \mathrm{kg} ; \mathrm{k}$ is the calorimeter coefficient in $\mathrm{kJ} /$ Celsius degrees; $\mathrm{T}_{\mathrm{f}}$ is the final temperature in ${ }^{\circ} \mathrm{C} ; \mathrm{T}_{\mathrm{i}}$ is the initial temperature in ${ }^{\circ} \mathrm{C} ; \mathrm{m}$ 
is the mass of the specimen in $\mathrm{kg}$; and $\mathrm{q}_{\mathrm{i}}$ is the supplementary heat given by cotton and nickel wire burning in $\mathrm{KJ}$.

The calorimetric installation software for determining the calorific value provided both the high and low calorific values and the burning time of the determination. In order to find the average value of the calorific value, $8-10$ valid replicates were used.

Calorific density and burning rate. The purpose of the caloric density determining was to determine the amount of energy that existed in relation with biomass volume and the necessary amount to determine the transport capacities of the truck or the storage silo of the thermal power plant. The calorific density $(\mathrm{CD})$ was obtained by taking into account the calorific value of the pellets and their effective density by using Equation (9):

$$
\mathrm{CD}=\mathrm{CV} \times \varrho\left[\mathrm{kJ} / \mathrm{cm}^{3}\right]
$$

where: $\mathrm{CV}$ is the calorific value in $\mathrm{kJ} / \mathrm{kg}$ and $\varrho$ is the density of the oven-dried pellets in $\mathrm{kg} / \mathrm{m}^{3}$.

The combustion speed of the biomass in the calorimeter was necessary in order to determine how fast the pellets burned, and in most cases this characteristic is used to determine the efficiency of the thermal power plant. Taking into account the burning time, the calorific value and the oven-dry mass, the burning rate was determined using Equation (10).

$$
\mathrm{BR}=\mathrm{CV}: \mathrm{t} \times \mathrm{m}_{0}[\mathrm{~kJ} / \mathrm{min}]
$$

where: $\mathrm{BR}$ is the burning rate in $\mathrm{KJ} / \mathrm{min} ; \mathrm{CV}$ is the calorific value expressed on a dry basis in $\mathrm{KJ} / \mathrm{kg}$; $\mathrm{m}_{0}$ is the mass of the oven-dried pellet in $\mathrm{g}$; and $\mathrm{t}$ is the combustion time in min.

The mean of BR value was obtained as an arithmetic mean of eight experiments, taking in consideration different values of time and calorific value, for each sample.

Influence of moisture content on calorific value. Because the moisture content of pellets was one of the principal factors that influenced the calorific value, a relationship of dependence for $0 \%$ and other moisture content values [17] could be found by using Equation (11):

$$
\mathrm{LCV}_{\mathrm{Mc}}=(\mathrm{CV} \times(100-\mathrm{Mc})-2.44 \times \mathrm{Mc}): 100[\mathrm{MJ} / \mathrm{kg}]
$$

where: $\mathrm{LCV}_{\mathrm{Mc}}$ is the low calorific value at a certain moisture content in $\mathrm{MJ} / \mathrm{kg} ; \mathrm{CV}$ is the calorific value for $0 \%$ moisture content in $\mathrm{MJ} / \mathrm{kg}$; and $\mathrm{Mc}$ is the moisture content in \%.

In order to determine this influence, the larch and oak pelleted specimens were kept in a climatic chamber until three moisture content values $(10 \%, 20 \%$ and $50 \%$ ) were obtained. The high and low calorific values $(\mathrm{HCV}, \mathrm{LCV})$ were determined from these tests. Thus, two straight lines were obtained in the $\mathrm{x} 0 \mathrm{y}$ plane (CV0Mc). The linear equations intersected the $\mathrm{CV}$ axis at the same point, and the horizontal Mc axis at two other different points. The arithmetic mean of the two horizontal intersections was defined as "limitative Mc". For example, if the larch pellets had a moisture content of $20 \%$, a calorific value of $15,499 \mathrm{~kJ} / \mathrm{kg}$ was obtained, and for a moisture content of $50 \%$, a calorific power value of $10,057 \mathrm{~kJ} / \mathrm{kg}$ was obtained. In this way, two points, A $(50 ; 10057)$, and B $(20 ; 15499)$ could be highlighted. A line can be made through the two points, whose gross equation was found using Equation (12):

$$
(y-10,037):(15,499-10,037)=(x-20):(50-20)
$$

By performing the calculations in the previous Equation (12), the final linear equation of the form $\mathrm{y}=\mathrm{n}-\mathrm{m} \cdot \mathrm{x}$ was obtained, with the calorific value being an unknown variable and the moisture content being a known variable, as seen in Equation (13):

$$
\mathrm{HCV}=19,140-150.8 \cdot \mathrm{Mc}
$$

This equation is interpreted in the sense that it has a coefficient of linear equation of 19,140 and a tangent of the slope of the linear equation of -150.8 , which means that 
it has an angle of over 80 degrees, and the calorific value for completely dry pellets is $19,140 \mathrm{~kJ} / \mathrm{kg}$.

In the second part of the experiments, the torrefied sawdust was compressed into cylindrical pellets (with a dimension of $10 \mathrm{~mm}$, a mass of $0.5-0.8 \mathrm{~g}$, and a length of 9-11 mm) using the same press (as part of a calorimeter bomb) (Figure 2). At least 12 pellets were obtained from each native/torrefied sawdust lot. Also, two different categories of pellets, one made from larch sawdust (Larix decidua) and the other made from oak (Quercus robur) sawdust, were made and analyzed.

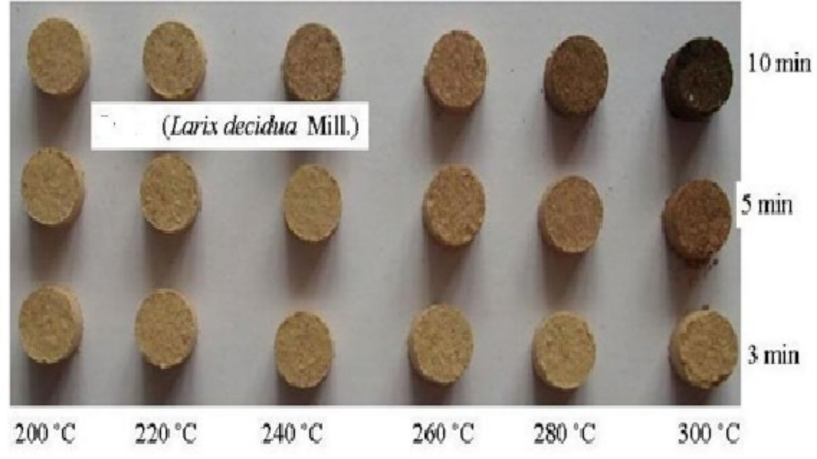

(a)

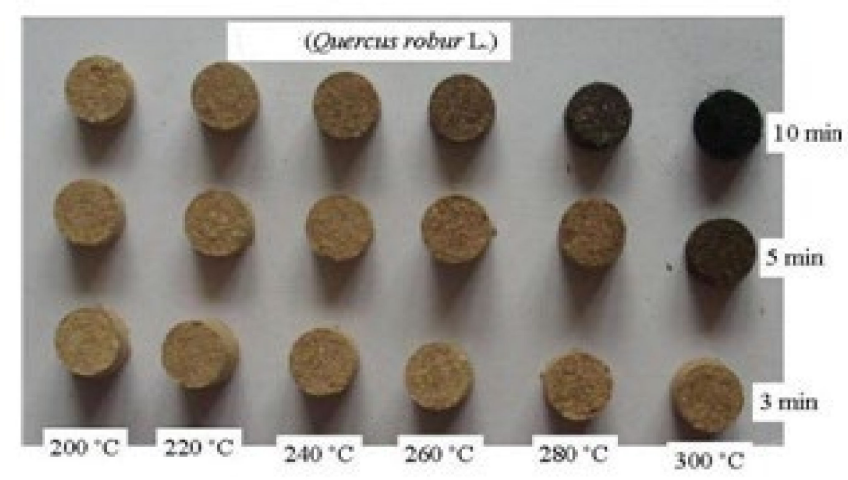

(b)

Figure 2. The torrefied pellets for larch (a) and oak (b).

The improvement in calorific value. The improving in calorific value after the thermal treatment of torrefaction was determined based on the calorific value obtained before and after treatment, depending on two parameters (temperature and treatment time), with aid of the next relation Equation (14):

$$
\mathrm{I}_{\mathrm{CV}}=(\mathrm{Cvat}-\mathrm{CVbt}): \mathrm{CVbt} \times 100[\%]
$$

where: $\mathrm{I}_{\mathrm{CV}}$ is the increase in calorific value $(\mathrm{CV})$ in \%; CVat is the calorific value after torrefaction in $\mathrm{kJ} / \mathrm{kg}$; and CVbt is the calorific value before torrefaction in $\mathrm{kJ} / \mathrm{kg}$.

Calorific efficiency. The calorific efficiency was determined in relation to moisture content. This determination was based on the fact that an increase in moisture content implicitly leads to a decrease in calorific value, and thus it was important to determine the percentage from the maximum caloric power (for $\mathrm{MC}=0 \%$ ) that was actually used during combustion and how much was lost through the drying of the pellets. This determination was based on tests performed to determine the influence of moisture content on the calorific value by referring to the maximum obtained calorific value $(\mathrm{CV})$. The calculation was performed as follows (Equation (15))

$$
\mathrm{Cef}=\mathrm{CV}_{\mathrm{Mc}}: \mathrm{CV} \times 100[\%]
$$

where: $\mathrm{CM}_{\mathrm{Mc}}$ is the calorific value for a certain moisture content in $\mathrm{kJ} / \mathrm{kg}$ and $\mathrm{CV}$ is the maximum calorific value for a moisture content of $0 \%$.

Proximate analysis was performed by determining volatiles, fixed carbon and ash content (Ac). The same calciner was used by means of a heat-resistant vessel with a lid, so that the sawdust did not oxidize during the elimination of volatile matter (VM). The amount of fixed carbon (FC) that was obtainedwhen the sawdust had a $0 \%$ moisture content, was calculated using the following Equation (16):

$$
\mathrm{FC}+\mathrm{VM}+\mathrm{Ac}=100[\%]
$$

Statistical analysis. In the first stage, the obtained values were subjected to the determination of the survey median and the standard deviation in order to observe the 
trend and the scattering of the values. Using Microsoft Excel, the standard error was applied to the graphs obtained for a $95 \%$ confidence interval. The obtained trend equations were chosen in such a way that the determination coefficient $R^{2}$ had a value higher or was appropriated to 0.9. Analysis of variance (AVOVA one-way) was used to compare two groups of values in order to study the dependency between a dependent variable (oak density) and an independent variable (larch density). The Minitab 18 program was also used for statistical analysis in order to obtain statistical graphs and determine other statistical parameters.

\section{Results}

\subsection{Granulometry of Native Sawdust}

The granulometry of the native sawdust (Figure 3) was almost identical for larch and oak, this being determined by the fact that the raw material was taken from the same circular saw and was sorted with the same $5 \mathrm{~mm} \times 5 \mathrm{~mm}$ sieve.

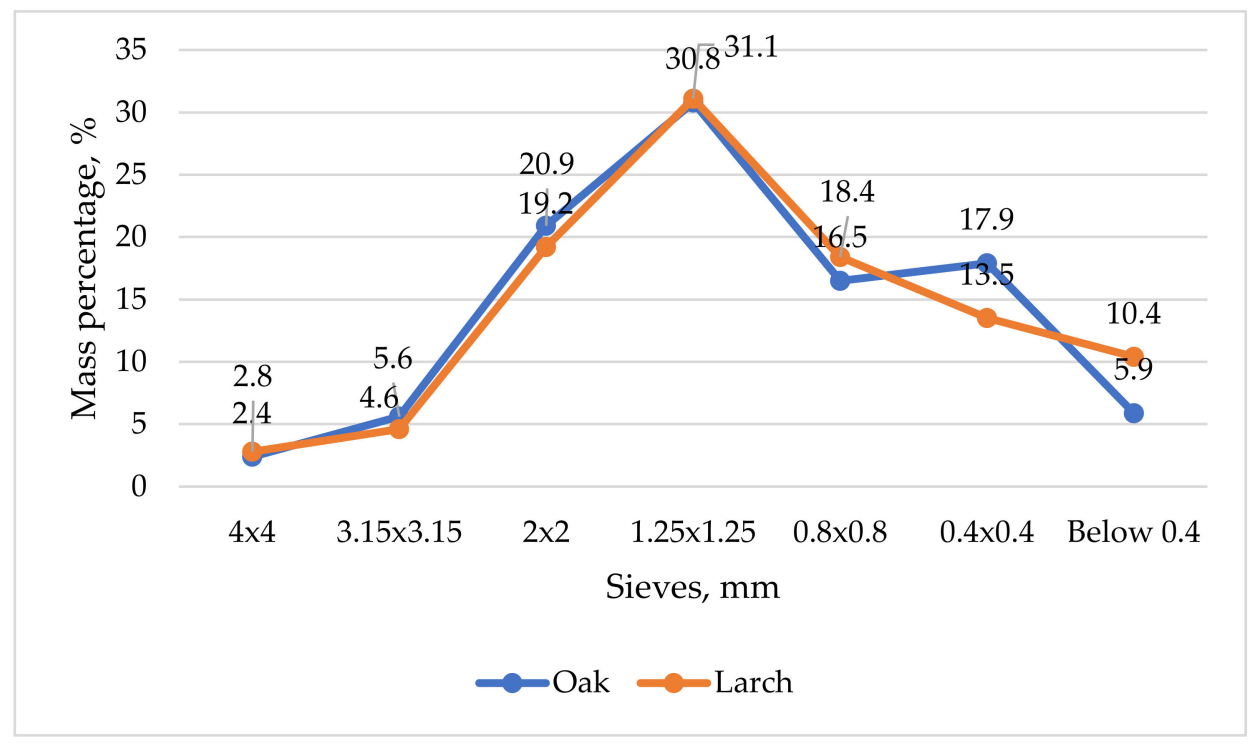

Figure 3. Granulometry of native sawdust.

The small variations observable in Figure 3 were determined by the different density of the two considered wood species

\subsection{Bulk Characteristics of Sawdust}

Following the procedure expressed in the previous chapter and Equation (2), a bulk density values of $162 \mathrm{~kg} / \mathrm{m}^{3}$ and $204 \mathrm{~kg} / \mathrm{m}^{3}$ were obtained for the larch and oak sawdust, respectively. The difference between the values was due to the large differences in the effective density of the two species, the calculated densities of oak and larch wood being $784 \mathrm{~kg} / \mathrm{m}^{3}$ and $575 \mathrm{~kg} / \mathrm{m}^{3}$, respectively. Moreover, the degree of compression of the sawdust of the two species was determined, taking into account the density of the wood substance (as the maximum value at which it can be compressed) for both species, which is $1450 \mathrm{~kg} / \mathrm{m}^{3}$. Using Equation (3), expansion coefficient values of 3.54 and 3.84 were obtained for larch and oak, respectively, as were other compression coefficient values, namely 8.9 for larch and 7.1 for oak. The compression ratio of larch was higher because the compaction started from a lower sawdust density value $\left(162 \mathrm{~kg} / \mathrm{m}^{3}\right)$ than in the case of oak $\left(204 \mathrm{~kg} / \mathrm{m}^{3}\right)$. Thus, the difference related the maximum value that can be reached in terms of compression was much larger. From this analysis, it can be concluded that heavier species (such as oak) have a lower compression than light species (such as larch). 


\subsection{Density of Native/Torrefied Pellets}

The moisture content of the sawdust and pellets was about $10 \%$, with this being determined by the classical gravimeter method, standardized by EN 14774-1:2009. The density of the native (un-torrefied) pellets was determined as a ratio between mass and volume and was about $1010 \mathrm{~kg} / \mathrm{m}^{3}$ for oak and $1012 \mathrm{~kg} / \mathrm{m}^{3}$ for larch. The density values were very appropriate because the dimensional characteristics of the sawdust were the same (a fraction smaller than $5 \mathrm{~mm} \times 5 \mathrm{~mm}$ was removed from the circular sawdust) and the pelletizing press and its parameters were the same in both cases.

\subsection{Calorific Features}

For both the two analyzed species (Quercus robur and Larix decidua) the burning time, higher and lower values of calorific power (HCV and LCV), lineal equation for each type of calorific value and limitative MC were calculated, specifically when native (no-treated) pellets were used (Table 1).

Table 1. Calorific characteristics of native [un-treated] pellets.

\begin{tabular}{|c|c|c|c|c|c|c|c|}
\hline \multirow{3}{*}{$\begin{array}{c}\text { Species } \\
\text { Oak }\end{array}$} & \multirow{3}{*}{$\begin{array}{c}\text { Time of Burning } \\
25\end{array}$} & \multirow{3}{*}{$\begin{array}{c}\text { HCV } \\
18,564\end{array}$} & \multirow{3}{*}{$\begin{array}{c}\begin{array}{c}\text { Calorific Value } \\
\text { LCV }\end{array} \\
18,563\end{array}$} & \multirow{3}{*}{$\frac{\text { CV }}{18,569}$} & \multirow{3}{*}{$\begin{array}{c}\text { Lineal Equation } \\
\mathrm{HCV}=18,569-176.4 \cdot \mathrm{Mc} \\
\mathrm{LCV}=18,569-195.1 \cdot \mathrm{Mc}\end{array}$} & \multirow{2}{*}{\multicolumn{2}{|c|}{ Limitative Mc, \% }} \\
\hline & & & & & & & \\
\hline & & & & & & $\begin{array}{c}105.2 \\
95.1\end{array}$ & 100.1 \\
\hline Larch & 29 & 19,135 & 19,132 & 19,140 & $\begin{array}{l}\mathrm{HCV}=19,140-150.8 \cdot \mathrm{Mc} \\
\mathrm{LCV}=19,140-279.4 \cdot \mathrm{Mc}\end{array}$ & $\begin{array}{c}126.9 \\
68.5\end{array}$ & 97.7 \\
\hline
\end{tabular}

As a general rule, the calorific value was proportional to depended indirectly on the moisture content, with both the both higher and lower calorific values decreasing with an increase in Mc. Ideally, if the pellets under analysis were absolutely dry, i.e., they would ideally have a moisture content of $0 \%$, then the two values, $\mathrm{HCV}$ and $\mathrm{LCV}$, would be equal and would have the unique value CV [28]. In reality, although the pellets were dried to a constant mass (i.e., they had $0 \% \mathrm{Mc}$ ), it was seen that the higher and lower calorific values were slightly different from each other. The explanation for this is the fact that a cleaner water with a volume of $3 \mathrm{~mL}$ was added into the bomb in order to absorb nitrogen compounds during burning. This explains the deviation from a moisture content value of $0 \%$ (to $2-4 \%$ ) and, consequently, from normal values of $\mathrm{CV}$. The addition of liquid water was strongly recommended by the calorimeter provider.

\subsection{Moisture Content Dependence on Caloric Power}

Based on the methodology presented in the previous chapter, the graphs in Figure 4 were obtained, both for the native oak sawdust and for the larch sawdust. The graphs show once again that the calorific values of the two species were different, with the calorific value of larch $(19,140 \mathrm{~kJ} / \mathrm{kg})$ being $3 \%$ higher than that of oak. The slight increase in calorific value for larch was due to the existence of a small amount of resin (which has a very high calorific value of about $34,000 \mathrm{~kJ} / \mathrm{kg}$ ) [24,26].

Figure 4 shows that with an increase of Mc, the calorific power will drop due to a certain amount of energy tat was used to dry the wooden pellets. The caloric value for $0 \%$ moisture content, noted with $\mathrm{CV}$, was obtained by mathematically determining the regression equation. These lineal equations are observed in Table 1. Cuttings of the horizontal axis of each lineal equation determined the limitative moisture content. When there was no rise in caloric energy, the mean values of limited moisture content were $100.1 \%$ and $97.7 \%$. The explanation for this is that the pellets' energy was equal to the energy used to consume water from wood (i.e., to dry out wood). When the moisture content is zero, both the HCV and LCV values were intersected, and a point with the same calorific value, $\mathrm{CV}$, was obtained. This is why the calorific efficiency issue occurred during the burning of the pellets with a certain Mc [29]. 


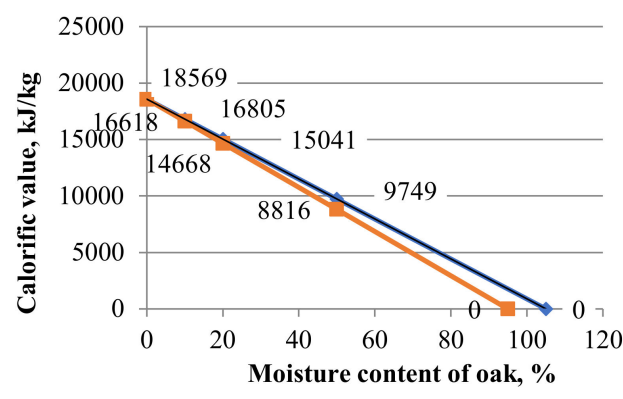

(a)

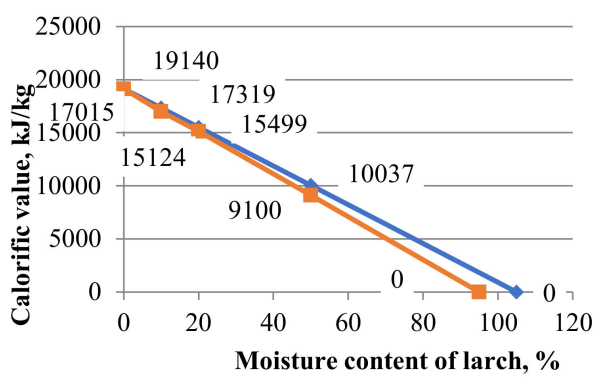

(b)

Figure 4. Calorific values for oak (a) and larch (b) in relation to moisture content.

\subsection{Calorific Efficiency}

With regard to calorific efficiency, Figure 5 shows that this property decreased with an increase in moisture content for oak and larch sawdust. Biomass with a $10 \%$ moisture content offered a better efficiency (95\%) than that with a moisture content of $50 \%$, the efficiency of which was $52 \%$.

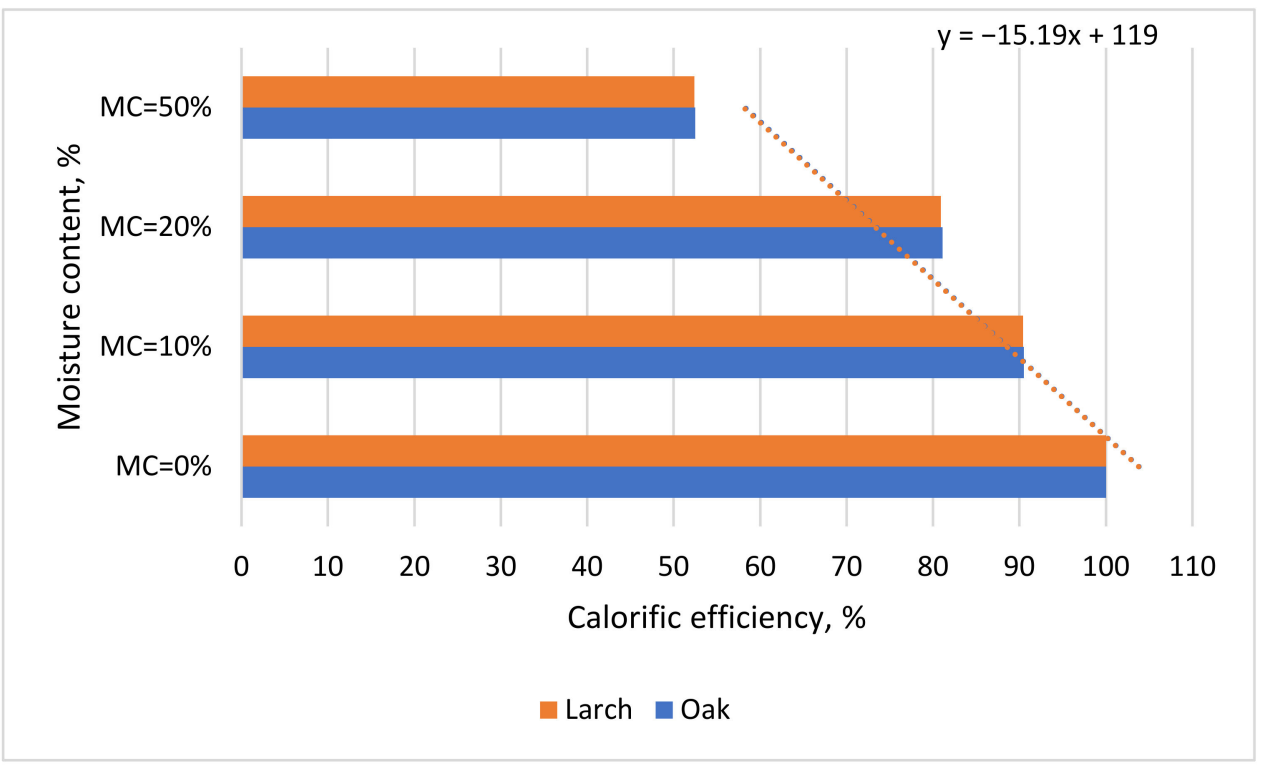

Figure 5. Calorific efficiency for larch and oak pellets.

\subsection{Calorific Density}

Regarding the energy properties of sawdust pellets, it was observable that the calorific density had extreme values, of $1.83-13.4 \mathrm{~kJ} / \mathrm{cm}^{3}$ for native larch pellets and $8.07-12.18 \mathrm{~kJ} / \mathrm{cm}^{3}$ for native oak pellets (Table 2). As a general rule, the calorific density decreased with an increased in pellet moisture content, with this decrease being 7.3 times for larch pellets and only of 1.5 times for oak pellets. These values show that the oak pellets were more homogeneous and had a more constant combustion. Also, the volume of the silo or means of transport would have to be slightly higher in the case of larch pellets, especially for a moisture content higher than $10 \%$. 
Table 2. Burning rate and calorific density.

\begin{tabular}{cccccc}
\hline \multirow{2}{*}{ Features } & & \multicolumn{3}{c}{ Moisture Content } \\
& & $\mathbf{0 \%}$ & $\mathbf{1 0 \%}$ & $\mathbf{2 0 \%}$ & $\mathbf{5 0 \%}$ \\
\hline \multirow{2}{*}{ Burning rate, $\mathrm{kJ} / \mathrm{min}$} & Larch & 463 & 313 & 86 & 47 \\
& Oak & 372 & 346 & 277 & 164 \\
Calorific density, $\mathrm{kJ} / \mathrm{cm}^{3}$ & Larch & 13.4 & 7.12 & 2.63 & 1.83 \\
& Oak & 12.18 & 11.06 & 10.89 & 8.07 \\
\hline
\end{tabular}

\subsection{The Burning Rate}

The burning rate decreased with an increase in moisture content (Table 2). The extreme values obtained for a moisture content of $0 \%$ and $50 \%$ showed a decrease of 9.8 times for larch pellets and 2.2 times for oak pellets. It was observed with respect to burning speed, that the oak pellets were more homogeneous, that their burning would be more constant and that there would be smaller differences when the moisture content varied within the same group of pellets.

\subsection{Mass Losses in Time of Torrefaction}

Generally, it was determined that when the degree of torrefaction is increased (given by the values of time and temperature), the mass loss will also proportionally increase (Figure 6). Temperatures over $260^{\circ} \mathrm{C}$ increased the mass loss [23-26] of oak pellets to a greater degree. A temperature of $300^{\circ} \mathrm{C}$ represented the ideal temperature for torrefaction but was the highest one possible before self-burning occurs. Knowing that the mass loss for non-torrefied sawdust is zero, the mass loss over the total temperature range for $3 \mathrm{~min}$ was $8.84 \%$, for $5 \mathrm{~min}$ was $16.95 \%$ and for $10 \mathrm{~min}$ was $40.24 \%$. In the case of larch sawdust, the increase was of $7.62 \%$ for $3 \mathrm{~min}, 16.95 \%$ for $5 \mathrm{~min}$ and $17.59 \%$ for $10 \mathrm{~min}$. It was observed that the oak sawdust had higher losses than the larch sawdust for all the treatment regimens and had a maximum increase of $128.7 \%$ for $10 \mathrm{~min}$ and $300^{\circ} \mathrm{C}$. Another conclusion was the observation that there was a substantial increase in losses when the temperature increased from 280 to $300{ }^{\circ} \mathrm{C}$ for both sawdust species, with a difference of $31.4 \%$ for oak and $9.9 \%$ for larch.

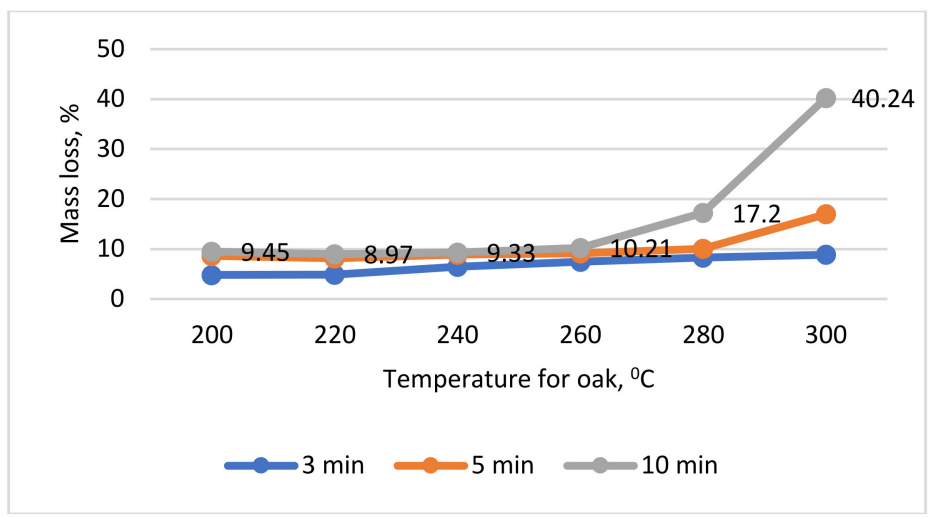

(a)

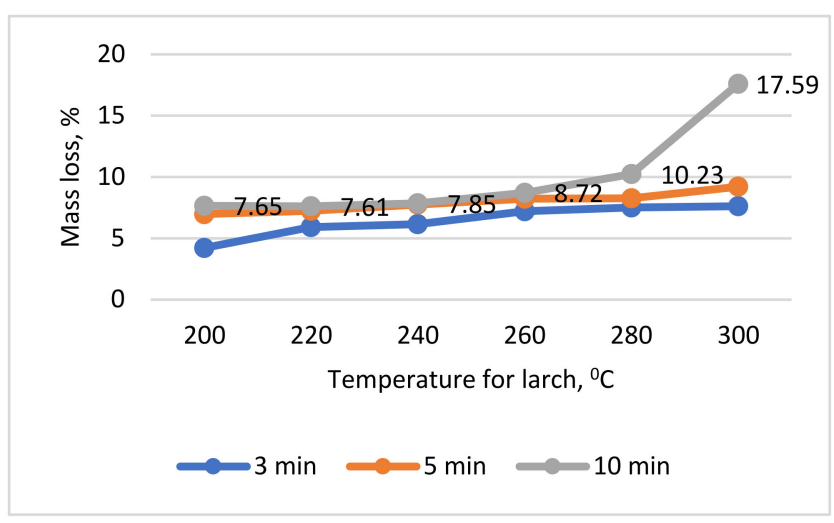

(b)

Figure 6. Mass losses for oak (Quercus robur L.) (a) and larch (Larix decidua Mill.) (b) sawdust during torrefaction.

\subsection{Increasing the Calorific Value When the Torrefaction Process Occurs}

With respect to the influence of temperature on the CV of Quercus robur pellets, Figure 7 reveals the increase in $\mathrm{CV}$ for treatments of $3 \mathrm{~min}, 5 \mathrm{~min}$ and $10 \mathrm{~min}$ in the case of larch pellets. Figure 8 reveals the increase in $\mathrm{CV}$ in the case of oak pellets. 


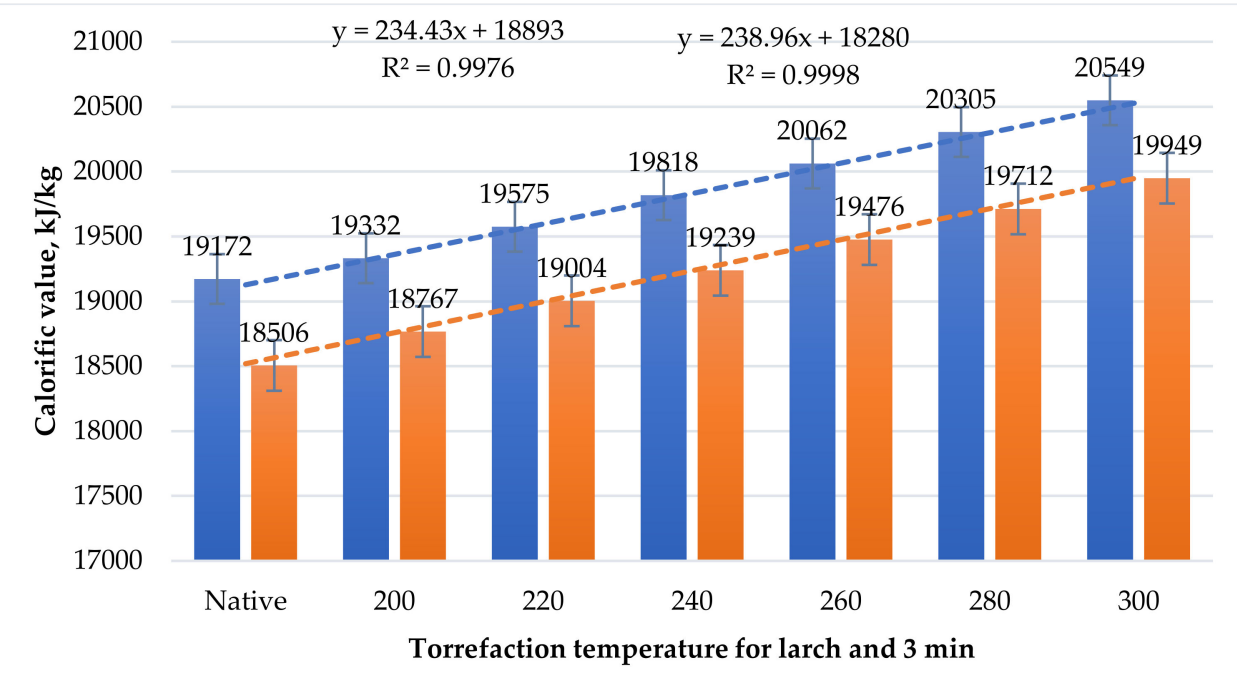

(a)

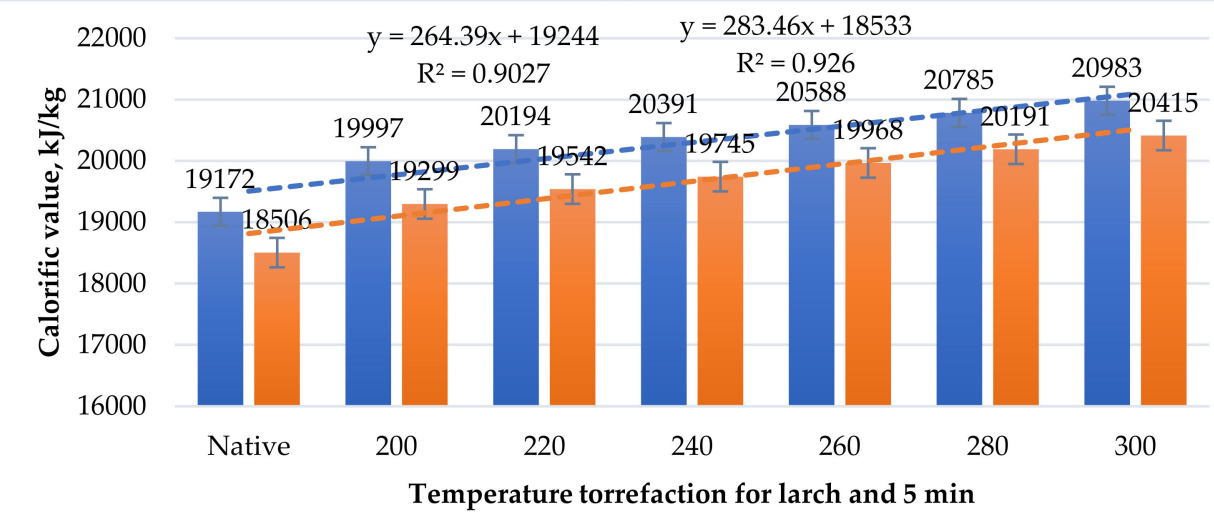

$\square \mathrm{HCV} \square \mathrm{LCV}$

(b)

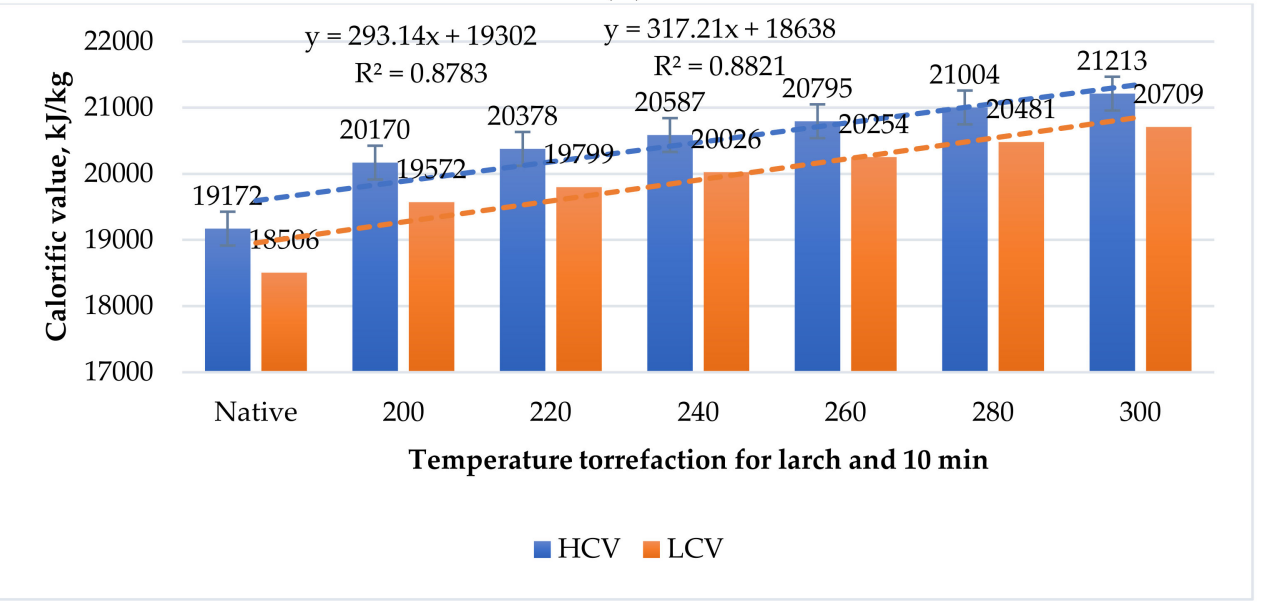

(c)

Figure 7. Calorific values for larch torrefaction for $3 \mathrm{~min}(\mathbf{a}), 5 \mathrm{~min}(\mathbf{b})$ and $10 \mathrm{~min}(\mathbf{c})$. 


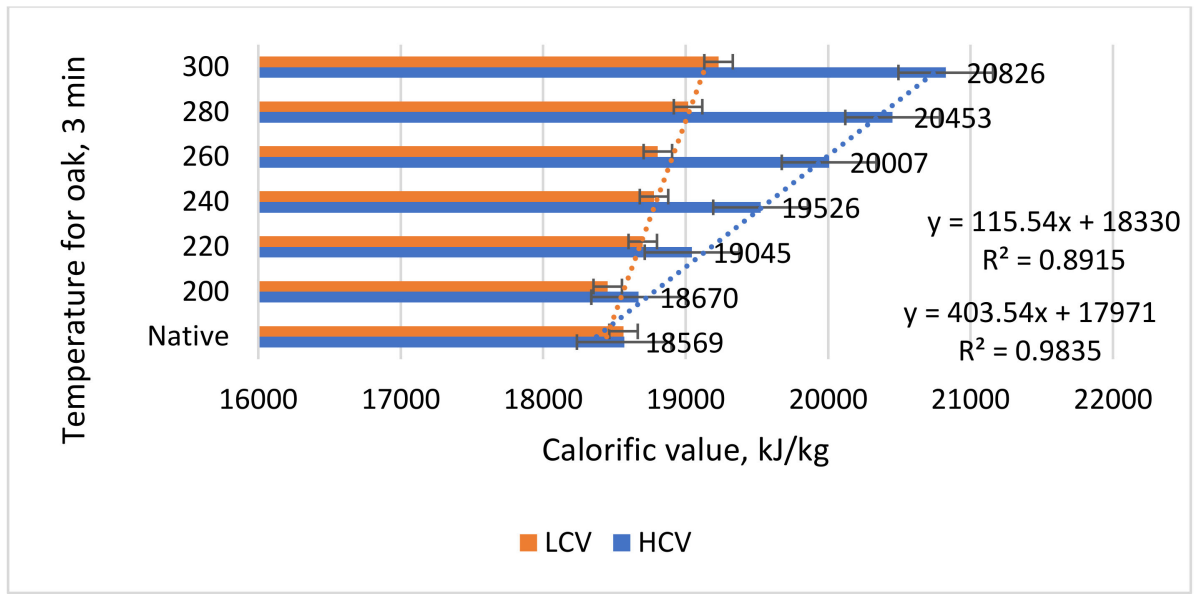

(a)

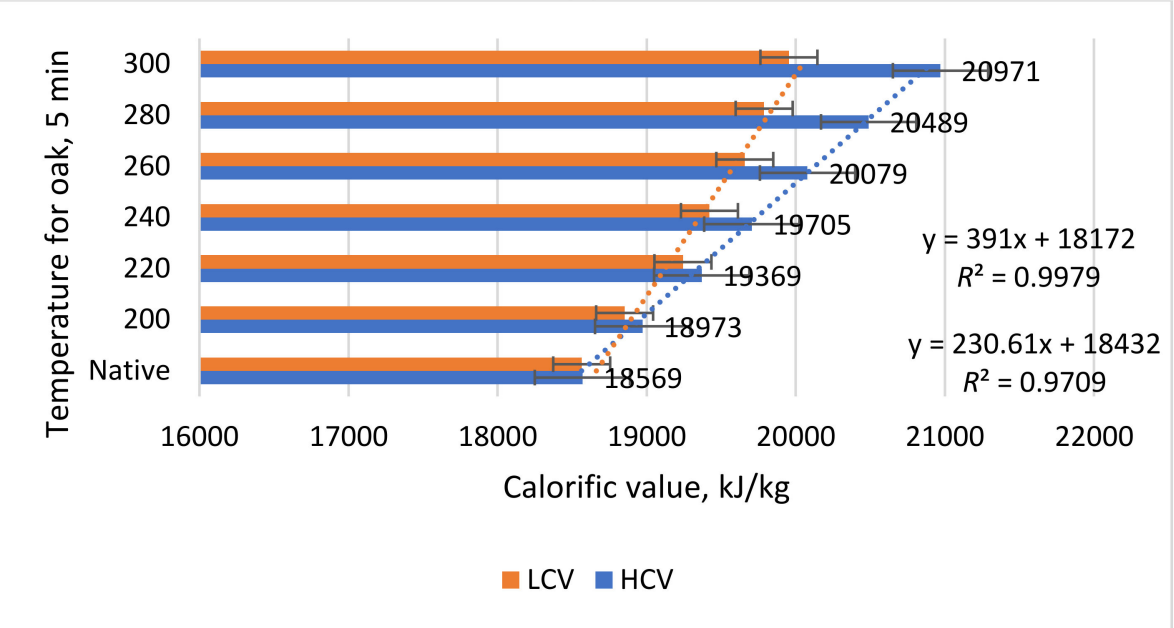

(b)

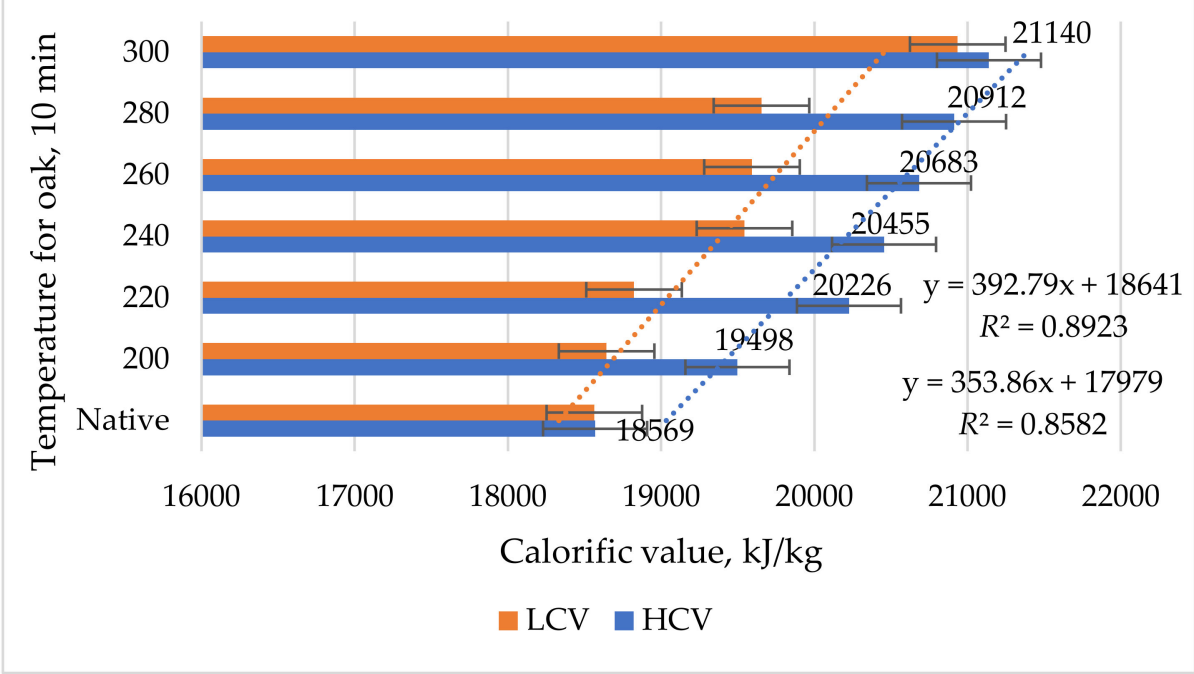

(c)

Figure 8. Calorific value of oak sawdust during torrefaction for $3 \mathrm{~min}(\mathbf{a}), 5 \mathrm{~min}(\mathbf{b})$ and $10 \mathrm{~min}$ (c).

Regarding the influence of torrefaction temperature and time on the $\mathrm{CV}$ of the pellets obtained from the larch sawdust (Figure 7), it can state that the highest increase in CV, $15.8 \%$, was obtained from the maximum torrefaction regime.

Throughout the heat treatment $\left(0-300{ }^{\circ} \mathrm{C}\right.$ and $\left.10 \mathrm{~min}\right)$ of the larch sawdust, the HCV increased, a with maximum of $15.5 \%$. It was observed that this increase does not correspond 
to the maximum mass loss, $17.9 \%$, because of other volatile substances that did not increase the calorific value, with the main factor influencing the increase in calorific value being the degradation of hemicelluloses [5].

As in the case of oak sawdust (Figure 8) was seen, the growth of HCV in the case of the larch does not correspond to the loss of mass, the former being much smaller. It should be noted that the $3 \mathrm{~min}$ period of torrefaction resulted in an increase of less than $5 \%$ in case of larch and oak sawdust. Also, the increase in calorific power to over $21,100 \mathrm{~kJ} / \mathrm{kg}$ made it possible to classify the torrefied pellets as inferior coke coals.

\subsection{Ash Content, Volatile Matter and Fixed Carbon}

Different values were obtained for the ash content of native sawdust, with a value of $0.42 \%$ for the Larix decidua and one of $0.51 \%$ for the Quercus robur sawdust (Figure 9 ). The ash content increased slightly as a result of torrefaction. On the other hand, the sawdust that was torrefied had a high ash content, but this was not totally in concordance with the mass losses found during torrefaction [26], which is usually lower. For instance, the higher values of ash content for torrefied sawdust highlighted during laboratory tests at $300{ }^{\circ} \mathrm{C}$ was $0.58 \%$ (an increase of $13.7 \%$, whereas the mass loss was $40.2 \%$ ) for oak and $0.47 \%$ (an increase of $11.9 \%$, whereas the maximum mass loss was $17.5 \%$ ) for larch. As other authors have stated before $[5,13]$, the main constituents of ash are silicates, oxides and hydroxides, sulphates, phosphates, carbonates, chlorides and nitrates, which means that it can be used as a fertilizer in agriculture.

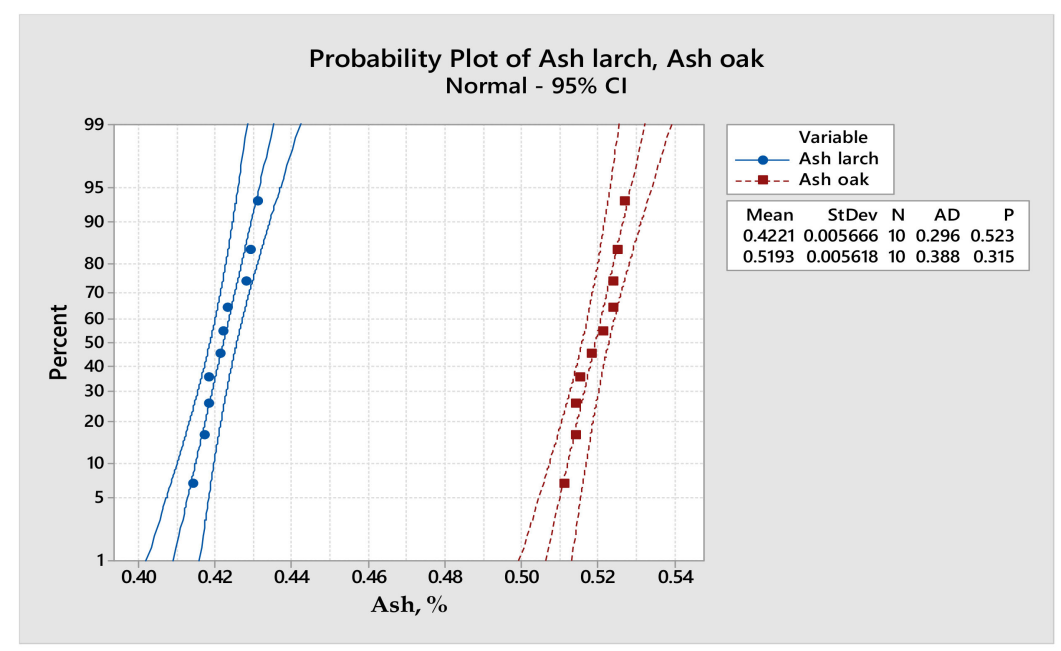

Figure 9. Probability plot for larch and oak ash content.

Proximate analysis of native and torrefied sawdust is available in Table 3.

Table 3. Proximate analysis of native/torrefied sawdust.

\begin{tabular}{ccccc}
\hline Specie & Type & Volatile Matter & Ash Content & Fixed Carbon \\
\hline \multirow{2}{*}{ Larch sawdust } & Native & 78.58 & 0.42 & 21 \\
& Torrefied & 61.53 & 0.47 & 38 \\
Oak sawdust & Native & 76.49 & 0.51 & 23 \\
& Torrefied & 53.42 & 0.58 & 46 \\
\hline
\end{tabular}

This proximate analysis highlights that by torrefying the sawdust was enriched with fixed carbon, losing some of its volatile materials. Some differences were found regarding the fixed carbon content of torrefied sawdust, with the value of $21 \%$ higher for oak. 


\section{Discussion}

The advantages of using the pelletizing process on larch sawdust have been highlighted by other researchers, namely the high durability $[10,13]$ achieved by increasing the calorific value [1] by about $18 \%$ and by torrefying the sawdust followed by palletization $[11,16]$. Replacing nitrogen with rarefied air during torrefying is just one of the alternative methods that have been proposed, along with replacing it with saturated steam [15], with pressurized air [14] or with roasting gas [18]. All these methods aim to reduce the cost of sawdust torrefying, but the price of the torrefied pellets obtained using these methods does not yet justify their benefits.

The dimensions of wood particles are essential when it comes to obtaining pellets with superior characteristics, which is why the sawdust used in this study had an average size of $1.3 \mathrm{~mm}$ (Figure 1). In the same way, researchers [11,16] have established that the high properties of pellets are obtained from the small particles, and [18] has studied the influence of particle size on pellet characteristics. From the point of view of granulometry, maximum values of about $31 \%$ were obtained when $1.25 \mathrm{~mm} \times 1.25 \mathrm{~mm}$ sieve was used, which means that the maximum dimensions of the chips were found in the area of the same sieve. Minimum values of about $2 \%$ were obtained when the $4 \mathrm{~mm} \times 4 \mathrm{~mm}$ sieve was used, because the $5 \mathrm{~mm} \times 5 \mathrm{~mm}$ sieve was used to remove the tendrils and also removed some of the large chips.

The three characteristics of the sawdust, namely bulk density, the expansion coefficient and the compression coefficient, were dependent on the dimensions of the chips with respect to their granulometry. Therefore, the values obtained were slightly different from those obtained by other authors [11].

Calorific values for wood pellets below $19,000 \mathrm{~kJ} / \mathrm{kg}$ were also obtained by [3,12], a loss of mass below $34 \%$ by [18], and an ash content below $1 \%$ by [22]. The densities of solid wood were statistically analyzed (Table 4) by means of analysis of variance (ANOVA). The values of the F-value and $p$-value parameters highlight the normality of the value distribution for a $95 \%$ confidence interval, as other researchers have stated before $[7,17]$.

Table 4. Analysis of variance for wood density.

\begin{tabular}{cccccc}
\hline Source & DF & Adj SS & Adj MS & F-Value & $p$-Value \\
\hline Larch density & 9 & 346.05 & 38.45 & 0.95 & 0.048 \\
Error & 1 & 40.50 & 40.50 & & \\
Total & 10 & 386.55 & & & \\
\hline
\end{tabular}

In the same analysis, the pellets densities differed by less than $0.2 \%$ and the $\mathrm{CV}$ of the native pellets differed by less than $3.1 \%$. Differences in the increase in calorific power after sawdust torrefaction were below $3.1 \%$ in favor of larch pellets [10]. Similar small differences were found for other features, such as caloric efficiency, energy release rate and calorific density [6].

The correlation between calorific value and degradation of main wooden compounds was achieved according to the main chemical compounds of wood, which are cellulose, hemi-cellulose and lignin. The influence of secondary chemicals (extractables and oxides from ash) was neglected. Of these major chemicals, lignin has the strongest influence on calorific value. Knowing that lignin has the highest calorific value, $25,121 \mathrm{~kJ} / \mathrm{kg}$ $(25.1 \mathrm{MJ} / \mathrm{kg})$, while cellulose and hemicellulose have a value of about $17374 \mathrm{~kJ} / \mathrm{kg}$ (17.3 MJ $/ \mathrm{kg}$ ), an addictive relationship could be identified (17):

$$
\mathrm{CV}=25,121 \times \mathrm{Li}: 100+17,374 \times(\mathrm{Ce}+\mathrm{He}): 100[\mathrm{~kJ} / \mathrm{kg}]
$$

where $\mathrm{CV}$ is the calorific value of sawdust in $\mathrm{kJ} / \mathrm{kg}$; $\mathrm{Li}$ is the content of lignin in $\% \mathrm{wt}$; $\mathrm{Ce}$ is the content of cellulose in \% wt; and He is the content of hemicelluloses in \% wt. 
The average values for lignin, cellulose and hemicellulose content were taken from the literature [27], and are 32\%, 46\% and 22\% for larch, respectively, and $32 \%, 45 \%$ and $23 \%$ for oak, respectively.

First, it should be considered that only hemicelluloses degrade up to $300{ }^{\circ} \mathrm{C}$ and cellulose is degraded after $300{ }^{\circ} \mathrm{C}$. Due to the total degradation of hemicelluloses, only cellulose and lignin remained in the torrefied product, with proportions of $39.2 \%$ and $60.8 \%$, respectively. Applying Equation (16) resulted in a calorific value of 20,354 kJ/kg for larch and $19,495 \mathrm{~kJ} / \mathrm{kg}$ for oak.

Second, during the torrefying process, all the cellulose can be degraded with the hemicellulose, and the maximum calorific value is $25,121 \mathrm{~kJ} / \mathrm{kg}$ for both species. In reality, after performing the torrefying test, the sawdust had a maximum calorific value of $21,040 \mathrm{~kJ} / \mathrm{kg}$ in the case of the oak and $21,213 \mathrm{~kJ} / \mathrm{kg}$ in the case of the larch, which means that only a certain amount of cellulose was degraded during the torrefaction process, about $6.5 \%$ for the larch and $13.7 \%$ for the oak. By looking closely at the torrefaction graphs (Figure 7), it can be found that the degradation of cellulose begins in the case of larch at a temperature of $220^{\circ} \mathrm{C}$ and at $215^{\circ} \mathrm{C}$ in the case of oak.In this time the cellulose degradation intensity wass lower than that of hemicelluloses.

\section{Conclusions}

Generally, wood biomass, such as larch and oak sawdust/pellets, is environmentally friendly and offers clean and quick energy without $\mathrm{CO}_{2}$ emissions.

The native larch and oak pellets had few differences in terms of effective density and calorific value, but after the thermal treatment of torrefaction the calorific value grew significantly, up to $15.8 \%$.

If a comparison of the calorific properties of larch and oak sawdust/pellets is made, it can be observed that, although they are two different species (softwood and hardwood) and have different densities $\left(775 \mathrm{~kg} / \mathrm{m}^{3}\right.$ in the case of oak and $521 \mathrm{~kg} / \mathrm{m}^{3}$ in the case of larch at $10 \%$ moisture content), their energetic properties after torrefaction are quite appropriate.

Considering that the two analyzed species (Quercus robur and Larix decidua) are valuable species which are mainly used in furniture, decorations, timber and veneers, etc., it is recommended that only their remnants from the processing of wood (sawdust, for example) should be used in the process of manufacturing native or torrefied pellets.

Author Contributions: Conceptualization, A.L.; methodology, C.S.; software, A.M.O.; validation, A.L.; formal analysis, A.M.O.; investigation, A.L.; resources, A.L.; data curation, C.S.; writingoriginal draft preparation, A.L.; writing-review and editing, A.L.; visualization, A.M.O.; supervision, A.M.O.; project administration, A.L. All authors have read and agreed to the published version of the manuscript.

Funding: This research received no external funding.

Data Availability Statement: Not applicable.

Acknowledgments: The authors would like to thank the Transilvania University of Brasov for their administrative and technical support.

Conflicts of Interest: The authors declare no conflict of interest.

\section{References}

1. Kambo, H.S.; Dutta, A. Strength, storage, and combustion characteristics of densified lignocellulosic biomass produced via torrefaction and hydrothermal carbonization. Appl. Energy 2014, 135, 182-191. [CrossRef]

2. Zarringhalam, M.A.; Gholipour, Z.N.; Dorosti, S.; Vaez, M. Physical Properties of Solid Fuel Briquettes from Bituminous Coal Waste and Biomass. J. Coal. Sci. Eng. China 2011, 17, 434-438. [CrossRef]

3. Kersa, J.; Kulu, P.; Aruniit, A.; Laurma, V.; Križan, P.; Šooš, L. Determination of Physical, Mechanical and Burning Characteristics of Polymeric Waste Material Briquettes. Est. J. Eng. 2010, 16, 307-316. [CrossRef]

4. Chen, N.; Rao, J.; He, M.; Mei, G.; Huang, Q.; Lin, Q.; Zeng, Q. Preparation and Properties of Heat- treated Masson Pine (Pinus Massoniana) Veneer. BioResources 2015, 10, 3451-3461. [CrossRef]

5. Esteves, B.; Pereira, H. Wood Modification by Heat Treatment: A Review. BioResources 2009, 4, 370-404. [CrossRef] 
6. Kumar, L.; Koukoulas, A.; Mani, S.; Satyavolu, J. Integrating Torrefaction in the Wood Pellet Industry: A Critical Review. Energy Fuel 2017, 31, 37-54. [CrossRef]

7. Akinrinola, F.S. Torrefaction and Combustion Properties of Some Nigerian Biomass. Ph.D. Thesis, School of Chemical and Process Engineering, The University of Leeds, Leeds, UK, 2014. Available online: https:/ / etheses.whiterose.ac.uk/8867/1/Femi\%20 Akinrinola_\%20thesis_white\%20rose_01052015.pdf (accessed on 19 January 2022).

8. Boutin, G.; Gervasoni, P.; Help, R.; Seyboth, K.; Lamers, P.; Ratton, M. Alternative energy sources in Transition Countries. The case of Bio-energy in Ukraine. Environ. Engine. Manag. J. 2007, 6, 3-11. [CrossRef]

9. McKendry, P. Energy Production from Biomass (part 2): Conversion Technologies. Bioresour. Technol. 2002, 83, 47-54. [CrossRef]

10. Ahn, B.J.; Chang, H.S.; Lee, S.M.; Choi, D.H.; Cho, S.T.; Han, G.S.; Yang, I. Effect of binders on the durability of wood pellets fabricated from Larix kaemferi C. and Liriodendron tulipifera L. sawdust. Renew. Energ. 2013, 62, 18-23. [CrossRef]

11. Peng, J.H.; Bi, H.T.; Sokhansanj, S.; Lim, J.C. A Study of Particle Size Effect on Biomass Torrefaction and Densification. Energ. Fuel 2012, 26, 3826-3839. [CrossRef]

12. Rudolfsson, M.; Borén, I.; Pommer, L.; Nordin, A. Combined effects of torrefaction and pelletisation parameters on the quality of pellets produced from torrefied biomass. Appl. Energ. 2017, 191, 414-424. [CrossRef]

13. Oh, S.-W.; Park, D.H.; Lee, S.M.; Ahn, B.J.; Ahn, S.H.; Yang, I. Torrefaction of Larix Kaempferi, C. and Liriodendron Tulipifera L. Cubes: Impact of Reaction Temperature on Microscopic Structure, Moisture Absorptivity, and the Durability of Pellets Fabricated with the Cubes. Energ. Fuel 2018, 32, 431-440. [CrossRef]

14. Nhuchhen, D.R.; Basu, P. Experimental Investigation of Mildly Pressurized Torrefaction in Air and Nitrogen. Energy Fuels 2014, 28, 3110-3121. [CrossRef]

15. Kudo, S.; Okada, J.; Ikeda, S.; Yoshida, T.; Asano, S.; Hayashi, J. Improvement of Pelletability of Woody Biomass by Torrefaction under Pressurized Steam. Energy Fuels 2019, 33, 11253-11262. [CrossRef]

16. Peng, J.W.; Bi, X.T.; Lim, C.J.; Sokhansanj, S.; Peng, H.; Jia, D. Effects of Thermal Treatment on Energy Density and Hardness of Torrefied Wood Pellets. Fuel Process. Technol. 2015, 129, 168-173. [CrossRef]

17. Eseyin, A.E.; Steele, P.H.; Pittman, C.U., Jr. Current trends in the production and applications of torrefied wood/biomass-A review. BioResources 2015, 10, 8812-8858. [CrossRef]

18. Granados, D.A.; Basu, P.; Chejne, J.F.; Nhuchhen, D.R. A Detailed Investigation into Torrefaction of Wood in a Two-Stage Inclined Rotary Torrefier. Energy Fuels 2016, 31, 647-658. [CrossRef]

19. Okoro, N.M.; Ozonoh, M.; Harding, K.G.; Oboirien, B.O.; Daramola, M.O. Potentials of Torrefied Pine Sawdust as a Renewable Source of Fuel for Pyro-Gasification: Nigerian and South African Perspective. ACS Omega 2021, 6, 3508-3516. [CrossRef]

20. Olugbade, T.O.; Ojo, O.T. Biomass Torrefaction for the Production of High-Grade Solid Biofuels: A Review. Bioenerg. Res. 2020, 13, 999-1015. [CrossRef]

21. Alokika; Singh, B. Production, characteristics, and biotechnological applications of microbial xylanases. Appl. Microbiol. Biotechnol. 2019, 103, 8763-8784. [CrossRef]

22. Pérez, J.F.; Pelaez-Samaniego, M.R.; Garcia-Perez, M. Torrefaction of Fast-Growing Colombian Wood Species. Waste Biomass Valori. 2019, 10, 1655-1667. [CrossRef]

23. Lee, J.; Karki, S.; Poudel, J.; Won, K.; Cheon Oh, L.S. Fuel characteristics of sewage sludge using thermal treatment. J. Mater. Cycles Waste Manag. 2019, 21, 766-773. [CrossRef]

24. Aguilar, F.X.; Mirzaee, A.; McGarvey, R.G. Expansion of US wood pellet industry points to positive trends but the need for continued monitoring. Sci. Rep. 2020, 10, 18607. [CrossRef] [PubMed]

25. Ahmad, I.; Lee, M.-S.; Goo, H.-K.; Lee, C.-Y.; Ryu, J.-H.; Kim, C.-H. Fuel pellets from fine paper mill sludge supplemented by sawdust and by refined recovered lubricating oil. BioResources 2021, 16, 1144-1160. [CrossRef]

26. Krajnc, N. Wood Fuel Handbook; Food and Agriculture Organization of the United Nations: Pristina, Kosovo, 2017. Available online: http:/ / large.stanford.edu/courses/2017/ph240/timcheck1/docs/fao-krajnc-2015.pdf (accessed on 11 May 2021).

27. ASTM E1755-01; Standard Method for the Determination of Ash in Biomass. Annual Book of ASTM Standards. American Society for Testing and Materials: Philadelphia, PA, USA, 2003.

28. TWH TermoWood Handbook, Edition 2.0. Finnish Thermo Wood Association, Helsinki, Finland. 2003. Available online: https: / / asiakas.kotisivukone.com/files/en.thermowood.palvelee.fi/downloads/tw_handbook_080813.pdf (accessed on 2 June 2017).

29. Sjostrom, E. Wood Chemistry: Fundamentals and Applications; Gulf Professional Publishing: London, UK, 1993 ; pp. $277-293$. 